\title{
Effect of Carburization Parameters on Hardness of Carburized Steel Using MOORA Approach
}

\author{
Abbas Khammas Hussein* Laith Kais Abbas ** \\ Asraa Kareem Hameed *** \\ *,**,***Department of Materials Engineering / University of Technology/ Baghdad/Iraq \\ *Email: abbas2000x@gmail.com \\ **Email: 1aithka2012@gmail.com \\ ***Email: sosaalmalky801@gmail.com
}

(Received 20 September 2017; accepted 26 February 2018)

https://doi.org/10.22153/kej.2018.02.001

\begin{abstract}
In this research, (MOORA) approach based- Taguchi design was used to convert the multi-performance problem into a single-performance problem for nine experiments which built (Taguchi ( $\left.\mathrm{L}_{9}\right)$ orthogonal array) for carburization operation. The main variables that had a great effect on carburizing operation are carburization temperature $\left({ }^{\circ} \mathrm{C}\right)$, carburization time (hrs.) and tempering temperature $\left({ }^{\circ} \mathrm{C}\right)$. This study was also focused on calculating the amount of carbon penetration, the value of hardness and optimal values obtained during the optimization by Taguchi approach and MOORA method for multiple parameters. In this study, the carburization process was done in temperature between $\left(850\right.$ to $950{ }^{\circ} \mathrm{C}$ ) for 2 to 6 hours. Quenching was done for the specimens after heat treatments in furnace chamber by using different quench solutions, water, salt and polyvinyl alcohol. Analysis of variances - (ANOVA) were performed for nine experiments in order to optimize the problem that was associated with multiple criteria (parameter) to achieve maximum hardness and depth penetration. The program results showed that the optimum conditions are carburization temperature $\left(950{ }^{\circ} \mathrm{C}\right)$, carburization time $\left(2 \mathrm{hrs}\right.$.), tempering temperature $\left(200^{\circ} \mathrm{C}\right)$, tempering time $(10 \mathrm{hrs}$.), and activator $(10 \mathrm{wt}$ \%). Furthermore, the best quenching media was the polyvinyl alcohol.
\end{abstract}

Keywords: ANOVA, Carburizing, hardness, MOORA, optimization, Taguchi.

\section{Introduction}

Alloys of iron and carbon are known as steel which their definite content of carbon with the range of (0.15-1.5\%) [1], Steel alloys with low percentage of carbon have similarity properties of iron, as the percentage increase the metal acquires hardness and becomes stronger but less ductile [2], hardness is increased in the outer layer of metal surface by a series of processes known as case hardening and there are several methods of hardening one of them called carburizing, which is considered as a very important process and it is performed to steel surface hardening [3, 4]. Stainless steel can be classified into three basic categories austenitic, ferritic and martensitic [5].
The crystals structure of steel can be determined by atomic arrangement. In general, there are two crystal structures of iron; one of them is bodycentered-cubic (BCC) and the other is the facecentered-cubic (FCC), the (FCC) atomic arrangement of structure have high solubility limit than a (BCC) structure, which belongs to the interstitial sites where carbon can sit between the iron atoms [6]. Casting processes usually used to introduce the alloying elements to the steel [7]. Surface hardening is a simple approach of hardening of the steel surface. This technique is used for low carbon steels, where the carbon is added to the external surface of the steel [8]. The process is generally done within austenitic range at temperature between $\left(850-950{ }^{\circ} \mathrm{C}\right)$ for mild 
steel in which at this temperature the carbon has a high solubility [9]. For a successful carburizing process done, three factors must be controlled very well (carburizing time, temperature and chemical composition) [10].

Bulan Abdullah et.al [11], studied the effect of paste carburizing treatment on hardness and tensile strength at different range of temperature (700 to $800^{\circ} \mathrm{C}$ ) and holding time (6 hours). The formation of high carburized layer associated with temperature and the results showed an increase in temperature which lead to improvement of tensile strength and hardness. Sorin Adrian Barabasi and Adriana Florescu [12], studied the hardness of (SAE 3310) and (SAE 4320) steels and clearly demonstrate an improvement in outcomes deep carburizing. A decrease in residual austenite content was observed and located on the surface of the piece after diffusion and spheroidization annealing, which leads to an increase the hardness. K. M. Boubaker et.al [13], studied nondestructive inspection for characterizing carburized steel according to a theoretical model and experiments verifications using the optical beam deflection test. Measurements focused on determining mechanical properties. K. Palaniradja et.al [14], tried to study the behavior of the surface hardness according to carbon penetration depth in (SAE 8620) and (AISI 3310) steel materials by using (Taguchi $\left(\mathrm{L}_{9}\right)$ array). The experiments showed that the observations are within a (95\%) condense level and conclude that the experimental result with a very low error, and hence (Taguchi's) design can be used to optimize the process parameters of gas carburizing in order to achieve the desired properties for the specimens. "Ravendra Singh" [15], studied the mild steel carburized under different temperature ranges and investigated the suitable temperature at which the mild steel gives the best results for the hardness and wear mechanical properties by using (Taguchi) approach. Maikon A. Birnfeld. et. al. [16], studied the residual stresses and surface roughness variations after shot peening and subzero treatment applied to carburize and quench (AISI P20) tool steel.

In this research, the optimization is carried out using (MOORA) approach to optimize the required carburization process parameters for the best properties in carburized mild steel. ANOVA (analysis of variance) was also applied to determine the effect of each parameter on the output i.e. hardness and penetration depth for mild steel.

\section{Experimental Procedure}

Table (1) shows the chemical composition for the sample of mild steel considered in this work. Samples with diameter $(10 \mathrm{~mm})$ and length $(30$ $\mathrm{mm}$ ) have been carburized. Carburization is done for period of time and quenched with a different solution following by a tempering within different time according to the factor level shown in table (2). Samples were cleaned with alcohol solution $\left(\mathrm{CH}_{3} \mathrm{COCH}_{3}\right)$ then embedded in carburization box that contains graphite up to $(90 \%)$ within activator $\left(\mathrm{BaCo}_{3}\right)$ up to $(10 \%)$ then the box sealed with clay to prevent the undesirable reactions. The factors and levels selected for the (DOE - design of experiment) analysis are shown in table (2). The carburized samples are quenched with different solution (water solution, salt solution and polyvinyl alcohol solution) and the specifications of this solution are shown in table (3).

Table 1,

Chemical composition of mild steel sample (ASTM/E/415-14).

\begin{tabular}{|c|c|c|c|c|c|c|c|c|c|c|}
\hline Elements & $\% \mathrm{C}$ & $\% \mathrm{Si}$ & $\% \mathrm{Mn}$ & $\% \mathbf{P}$ & $\% \mathrm{~S}$ & $\% \mathrm{Ni}$ & $\% \mathrm{Al}$ & $\% \mathrm{Co}$ & $\% \mathrm{Cu}$ & $\% \mathrm{Nb}$ \\
\hline $\begin{array}{l}\text { Average. } \\
\text { Contact }\end{array}$ & 0.122 & 0.0005 & 0.442 & 0.0005 & 0.0269 & 0.0119 & 0.0052 & 0.001 & 0.0135 & 0.001 \\
\hline Elements & $\% \mathrm{~W}$ & $\% \mathrm{Ta}$ & $\% \mathrm{Sn}$ & $\% \mathrm{Zr}$ & $\% \mathrm{Zn}$ & $\% \mathrm{Cr}$ & $\% \mathrm{Mo}$ & $\% \mathrm{Ti}$ & $\% \mathrm{~V}$ & $\% \mathrm{Fe}$ \\
\hline $\begin{array}{l}\text { Average } \\
\text { Contact }\end{array}$ & 0.0056 & 0.0082 & 0.001 & 0.0064 & 0.0036 & 0.0097 & 0.001 & 0.0005 & 0.0009 & Rem \\
\hline
\end{tabular}


Table 2,

Factors and their levels of carburization.

\begin{tabular}{|c|c|c|c|c|}
\hline Factor & Factor code & $\begin{array}{l}\text { Levels } \\
1\end{array}$ & 2 & 3 \\
\hline Carburization Temp. $\left({ }^{\circ} \mathrm{C}\right)$ & $\mathrm{A}$ & 850 & 900 & 950 \\
\hline Carburization time (hrs.) & $\mathrm{B}$ & 2 & 4 & 6 \\
\hline Tempering temperature $\left({ }^{\circ} \mathrm{C}\right)$ & $\mathrm{C}$ & 200 & 250 & 300 \\
\hline Tempering time & $\mathrm{D}$ & 1 & 1.5 & 2 \\
\hline Activator wt. $\%$ & $\mathrm{E}$ & 10 & 10 & 10 \\
\hline Quench Media & $\mathrm{F}$ & Water & Brine & Polyvinyl alcohol \\
\hline
\end{tabular}

Table 3,

Characteristics of the used quenching medias.

Salt specification

Material

$\left(\mathrm{SO}_{4}\right)$

$(\mathrm{Fe})$

$(\mathrm{Pb})$

(K)

Impurity limit $\left(1050{ }^{\circ} \mathrm{C}\right)$.
Polyvinyl alcohol specification

Poly vinyl alcohol (PVA): $99 \%$ hydrolyzed

$0.002 \%$

$0.002 \%$

$0.0005 \%$

$0.02 \%$

$1.0 \%$
Grinding and polishing processes were applied for microstructure examination. Grinding and polishing were carried out using (silicon carbides (SiC) papers $(320,400,600,800,1000,1200))$ followed by etching process by using (Nital ( $2 \%$ nitric acid \& $98 \%$ alcohol)) then the specimen is examined under microscope and the amount of depth penetration was then calculated, figure (1) shows microstructure of penetration for the carburized sample.

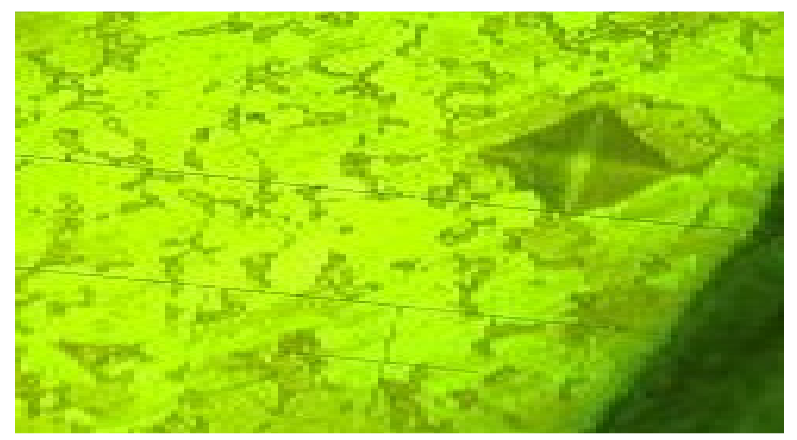

Fig. 1. Microstructure of penetration for the carburized sample $(\mathbf{1 0 0 0 x})$.

The pyramid diamond is forced into the surface of the specimen and the ratio of the applied load divided by the pyramidal area of the indentation, determination of the Vickers hardness $(\mathrm{HV})$ is done according to the following equation: $\mathrm{VHN}=\frac{1.845 \mathrm{p}}{\mathrm{d}^{2}}$

Where: $\mathrm{p}=$ amount of Applied load $(\mathrm{kg})$.
$\mathrm{D}=$ represent the length of the diagonals impression [17]. The amount of applied load is $(2.49 \mathrm{~N}(0.3 \mathrm{Kg}))$.

\subsection{MOORA Approach}

Multi-response optimization, also known as multi-performance optimization, is the process of optimizing two or more responses subjected to certain conditions. The MOORA- approach was first discovered by "Brauers" in (2004) which was a multi- performance optimization technique that can be effectively solve several types of complex problems related to multi-responses in many applications. The (Multi-Objective Optimization on the basis of Ratio Analysis- (MOORA)) approach starts with a decision matrix as expressed as follows [18].

$$
\mathrm{D}=A 3 \quad \begin{array}{c|ccccc}
A 1 & C 1 & C 2 & C 3 & \ldots & C n \\
A 2 & X 11 & X 12 & X 13 & \ldots & X 1 n \\
\vdots & X 31 & X 22 & X 23 & \ldots & X 2 n \\
A n & \vdots & \vdots & \vdots & \ddots & \vdots \\
X m 1 & X m 3 & X m 3 & \ldots & X m n
\end{array} \mid
$$

The procedure for using (MOORA) for ranking alternatives is:

Step 1: Determine the normalized decision matrix by vector method as defined as follows:

$X_{i j}^{\prime}=\frac{X_{i j}}{\sqrt{\sum_{i=1}^{m} X_{i j}^{2}}}$

Where: $i=1, . ., m ; j=1, \ldots, n$.

Step 2: Determine composite score as expressed in Equation (4):

$Z_{i}=\sum_{j=1}^{b} X_{i j}^{\prime}-\sum_{j=b+1}^{n} X_{i j}^{\prime}$ 
Where: $\left(\sum_{j=1}^{b} X_{i j}^{\prime}\right)$ and $\left(\sum_{j=b+1}^{n} X_{i j}^{\prime}\right)$ are benefit and non-benefit criteria, respectively and if there are responces more important than others, also $(i=1 \ldots m)$, the composite score of these attributes become as expressed in equation (5):

$Z_{i}=\sum_{j=1}^{b} W_{j} X_{i j}^{\prime}-\sum_{j=b+1}^{n} W_{j} X_{i j}^{\prime}$

Where: $W_{j}$ is the weight of $\left(j^{\text {th }}\right)$ criteria.

Step 3: Rank the alternatives in descending order. Figure (2) shows the flowchart of (MOORA) approach.

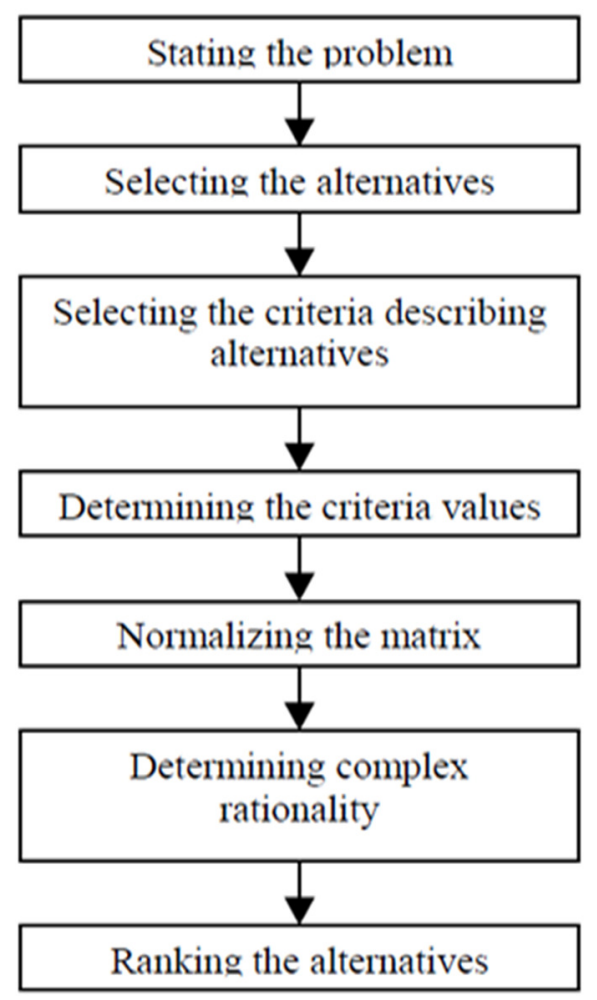

Fig. 2. Flowchart of (MOORA) approach.

\subsection{Multi - perform optimization}

Multi-performance optimization is an area of multiple response criteria, which is concerned with multiple optimization problems which include several objective functions to be optimized simultaneously. In practical problems, there can be more than three objectives [19].

\subsection{Signal-to-Noise Ratio (S/N):}

$(\mathrm{S} / \mathrm{N})$ ratio according to (Taguchi) design method is a measure of robustness used to identify variability in a product or process by reducing the effects of noise factors and control factors. In (Taguchi) design experiment, noise factors can be manipulated to force variability to occur and from the results, identify optimal control factor settings that robust, or resistant to variation from noise factors. The $(\mathrm{S} / \mathrm{N})$ ratio reassures how the response varies relative to the target value under different noise conditions [20].

\section{Results and Discussion}

The effective case depth is at a depth of about $(4 \mu \mathrm{m})$ where the surface hardness is approaching (300 HV). This is can be attributed to the nature of carburized case structure which can be martensitic or bainitic [21]. The experimental results were manipulated for case depth (carbon penetration depth). The microhardness results were analyzed using (MOORA) method. The results were feed into the (MINITAB) software to determine the corresponding $(\mathrm{S} / \mathrm{N})$ ratios. The analysis results are in table (5) and figure (3). It was found that the maximum value of microhardness reached at carbon penetration depth of $(4 \mu \mathrm{m})$ which may attribute to the nature of factor settings for experiment (No. 4).

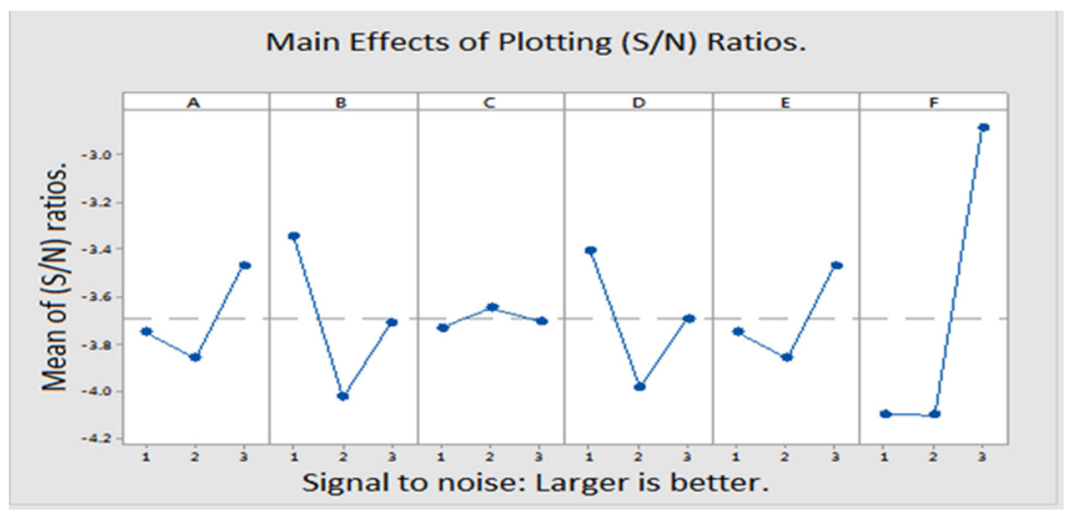

Fig. 3. Means of $(\mathrm{S} / \mathrm{N})$ ratios. 
Table 4,

Results of (MOORA) approach.

\begin{tabular}{llllcccl}
\hline $\begin{array}{l}\text { Exp. } \\
\text { No. }\end{array}$ & $\begin{array}{l}\text { Case depth } \\
(\boldsymbol{\mu m})\end{array}$ & $\begin{array}{l}\text { Micro hardness } \\
(\mathbf{H V})\end{array}$ & $\begin{array}{l}\text { Depth } \\
\text { Penetration }\end{array}$ & $\begin{array}{c}\text { Normalization } \\
\text { micro hardness }\end{array}$ & $\begin{array}{l}\text { Beneficial } \\
\text { attributes }\end{array}$ & $\begin{array}{l}\text { S/N } \\
\text { MOORA } \\
\text { rank }\end{array}$ \\
\hline 1 & 5.4628 & 147.066 & 0.296644 & 0.271089 & 0.567733 & -3.6 & 9 \\
2 & 5.857 & 183.2 & 0.31805 & 0.337695 & 0.655745 & -4.6 & 3 \\
3 & 5.5408 & 154.333 & 0.30088 & 0.284484 & 0.585364 & -1.1 & 8 \\
4 & 5.5408 & 312.63 & 0.30088 & 0.576275 & 0.877155 & -4.6 & 1 \\
5 & 4.4938 & 186.8 & 0.244025 & 0.344331 & 0.588356 & -4.5 & 7 \\
6 & 4.646 & 185.533 & 0.25229 & 0.341996 & 0.594285 & -3.8 & 6 \\
7 & 7.4448 & 129.17 & 0.404272 & 0.238101 & 0.642373 & -3.6 & 5 \\
8 & 8.242 & 125.433 & 0.447562 & 0.231212 & 0.678774 & -3.8 & 2 \\
9 & 6.96 & 125.8 & 0.377946 & 0.231889 & 0.609835 & -4.6 & 4 \\
\hline
\end{tabular}

The (MOORA) method was used to find out the best conditions or parameters for carburized steel and the results from table (4) and figure (3) shows that the optimum conditions are carburization temperature $\left(950^{\circ} \mathrm{C}\right)$, carburization time $\left(2 \mathrm{hrs}\right.$.), tempering temperature $\left(200{ }^{\circ} \mathrm{C}\right)$, tempering time (10 hrs.), activator (10 wt. \%) and quench media polyvinyl alcohol.

Metallographic examination is a powerful tool for the study of carburized steels and invaluable for diagnosing failures. In assessing the carbon penetration depth, metallographic are usually requested to measure the total carbon penetration depth or the effective carbon penetration depth. Figure (4) illustrates typical microstructures of carburized steel specimens with varying carburizing process parameters according to (Taguchi) array. This figure shows the influence of the ferratic that present in subsurface microstructure, which is effect on the microhardness value of carburized steel. Depths of carbon start from surface towards core at values from (4.4938 $\square \mathrm{m})$ to $(8.242 \square \mathrm{m})$.

ANOVA analysis was used to analyze the effects of carburization temperature, carburization time, tempering temperature, tempering time, activator and quench media on hardness property. In this analysis, the percentage contributions of control factors were used to evaluate the corresponding effects on the performance characteristics. The performed experimental plan was evaluated at a $(a=0.05$ confidence level). According to the results of (ANOVA) showed in table (6), tempering time had a dominant effect $(24.63 \%)$ on the quality characteristics. This parameter was followed by tempering temperature with a ratio of $(24.51 \%)$.

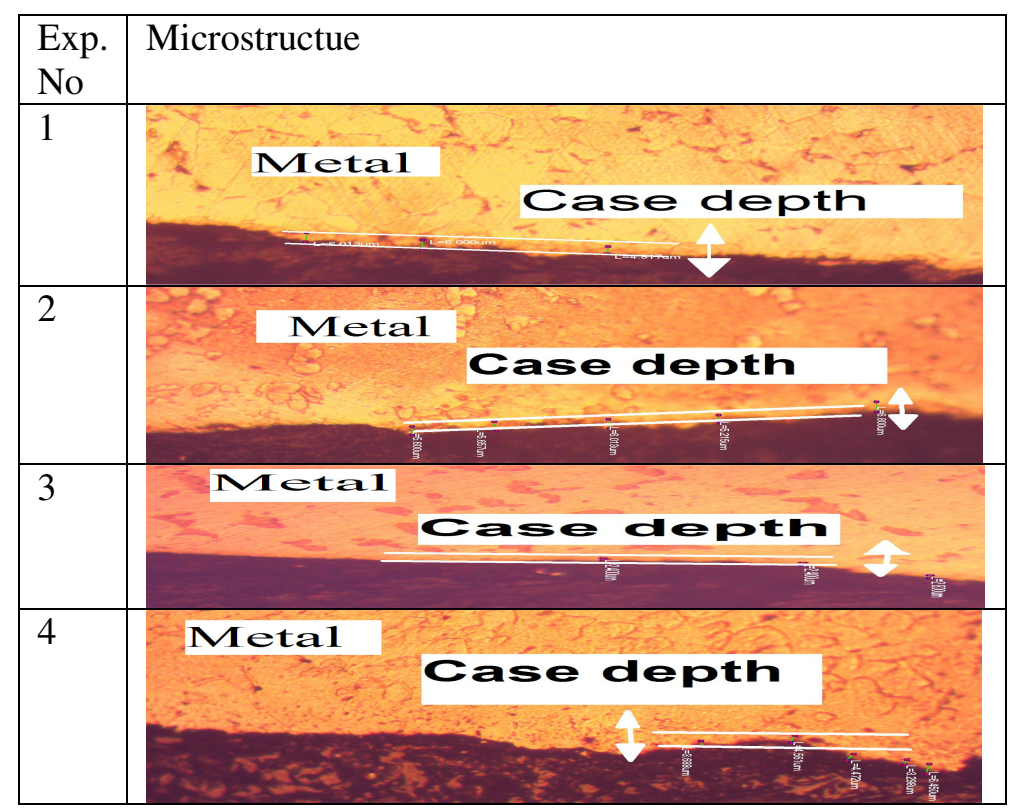




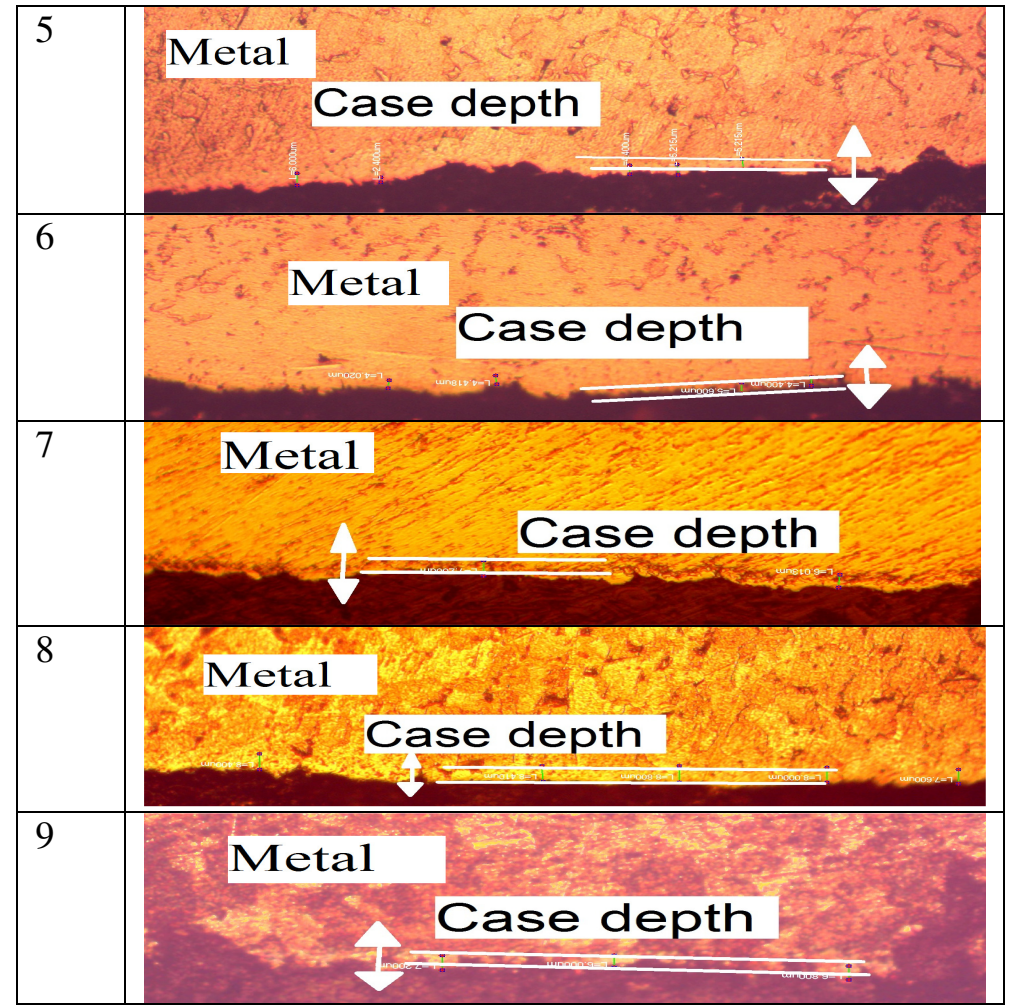

Fig. 4. Microstructures and penetration depth of carburized specimens according to (Taguchi) array (1000x).

Table 6, ANOVA Table

\begin{tabular}{lllll}
\hline Parameter & Degree of Freedom & Sum of Square & Mean Sum of Square & Contribution (\%) \\
\hline A & 5 & 0.011 & 0.002 & 10.58 \\
B & 5 & 0.022 & 0.004 & 22.22 \\
C & 5 & 0.024 & 0.005 & 24.51 \\
D & 5 & 0.024 & 0.005 & 24.63 \\
E & 5 & 0.011 & 0.002 & 11.23 \\
F & 5 & 0.007 & 0.001 & 6.84 \\
Total & & 0.099 & & \\
\hline
\end{tabular}

\section{Conclusions}

MOORA-based Taguchi's design method can be used to determine the optimal carburization parameters for the carbon steel alloy studied in the paper. From the results, it was found that:

1. The (MOORA) method was applied to determine the most optimum conditions for carburizing process of steel and the results show that the optimum conditions are, carburization temperature $\left(950 \quad{ }^{\circ} \mathrm{C}\right)$, carburization time (2 hrs.), tempering temperature $\left(200^{\circ} \mathrm{C}\right)$, tempering time $(10 \mathrm{hrs}$.), activator $(10$ wt. \%) and quench media polymer to get the optimum results for the carburizing.

2. Based on (ANOVA) method, the highly effective parameters on carburizing process are found as tempering time which had a dominant effect $(24.63 \%)$ on the quality characteristics and tempering temperature with a ratio of $(24.51 \%)$.

3. The results show that the hardness was greatly improved according to (Taguchi) array.

\section{Reference}

[1] D. A. Fadare, T. G. Fadara and O. Y. Akanbi, "Effect of heat treatment on mechanical properties and microstructure of (NST 37-2) steel", Journal of Minerals \& Materials Characterization \& Engineering, Vol. 10, No.3, pp: (299-308), 2011. 
[2] D. Gandy, "Carbon Steel ", Handbook, Electric Power Research Institute, pp: (2-4), March, 2007.

[3] A. Clark, "Comparison of tempering and quench and tempering processes for carburized automotive steels", M.Sc. Thesis Submitted to University of Windsor, 2013.

[4] A. J. Patel, S. N. Chaudhari, "Effect of different tempering temperatures and different load on wear behavior and mechanical properties on mild steel", International Journal of Advance Engineering and Research Development, Vol. 2, Issue 10, pp: (69-76), October, 2015.

[5] William D. Callister, "Materials science and Engineering", University of Utah, Salt Lake City pp: (325-326), 2007. [10]

[6] C. M. Méndez, M. M. Covinich, A. E. Ares, "Resistance to corrosion and passivity of 316L stainless steel directionally solidified samples", In Tech., CC BY 3.0 License, Book edited by M. Aliofkhazraei, ISBN: 978-95351-1223, http:// dx.doi.org/10.5772/57275, (2014).

[7] O.S. Fatoba1, O. 1. Akanji, A. S. Aasa, "Optimization of carburized UNS G10170 steel process parameters using (Taguchi) approach and response surface model (RSM)", Journal of Minerals and Materials Characterization and Engineering, Vol. 2, pp: (566-578), 2014.

[8] J. Gupta, "Mechanical and wear properties of carburized mild steel samples", Mechanical Engineering, M.Sc. thesis submitted to the National Institute of Technology, Rourkela, May, 2009.

[9] E. Santuliana, "Effect of surface treatments on mechanical properties of low alloy sintered steels", Ph.D. Thesis Submitted to University of Trenno -Italy, April, 2011.

[10] A. K. Hussein, L.K. Abbas, J. J. Dawood and N.J. Ismae, "Modeling of Carburization Parameters Process for Low Carbon Steel", Eng. \& Tech. Journal, Vol. 34, Part (A), No. 6, pp: (1069-1079), 2016.

[11] Bulan Abdullah, S.K. Aliasa, Ahmed Jaffara, Syazuan Abdul Latipa, Salmiah Kasolanga, Mohd Faizul Izhama, Muhd Azimin Abd Ghania, "Mechanical properties of paste carburized ASTM A516 steel", The Malaysian International Tribology Conference, MITC, pp: (525530), 2013.

[12] S. A. Barabasi, A. Florescu, "Optimization of deep carburizing heat treatment",
International Journal of Information Technology and Business Management, Vol.32, No.1, pp: (23-28), December, 2014.

[13] J. Petrik, "The microhardness of heat treated carbon steel, department of integrated management", Metallurgical Faculty, Materials science (MEDŽIAGOTYRA). Vol. 20, No. 1, pp: (21-24), 2014.

[14] K. Palaniradja, N. Alagumurthi, V. Soundararjan, "Optimization of Process Variables in Gas Carburizing Process: A Taguchi Study with Experimental Investigation on SAE 8620 and AISI 3310 Steels", Pondicherry Engineering College, Vol. 29, pp: (279-284), 2005.

[15] R. Singh, "Investigation of Optimal Process Parameters for Mechanical and Wear Properties of Carburized Mild Steel using Taguchi Approach", Int. J. Eng. Sci. Adv. Research, Vol. 1, No. 1, pp: (90-92), March, 2015.

[16] M. A. Birnfeld, G. Pintaúde, J. C. K. das Neves, "Effect of carburized steel hardness on surface roughness and residual stresses after manufacturing operations", International Congress of Mechanical Engineering, Vol. 20, pp: (57-64), Gramado, RS, Brazil ,15-November-2009.

[17] V.B. Cassapi, "Application of rock hardness and abrasive indexing to rock excavating equipment selection". $\mathrm{PhD}$ thesis, Submitted to University of Nottingham, (1987).

[18] K. Genel, M. Demirkol, "Effect of case depth on fatigue performance of AISI 8620 carburized steel", International Journal of Fatigue, Vol. 21, pp: (207-212), 1999.

[19] W. Karel, M. Brauers, E. K. Zavadskas, "The MOORA method and its application to privatization in a transition economy", Control and Cybernetics, Vol. 35, No. 2, pp: (207-212), 2006.

[20] H. Singh, "Taguchi Optimization of Process Parameters: A review and case study", International Journal of Advanced Engineering Research and Studies EISSN2249-8974, Vol. 1, issue 11, AprilJune, pp: (39-41), 2012.

[21] F. George. V. Voort, F. Gabriel, M. Lucas, "Microstructural Characterization of Carburized Steels", Heat Treating Progress, 4 Edt September, 2009. 


\title{
دراسة تأثثر الكربنة على صلادة الفولاذ المكربن بأستخدام طريقة ـورا
}

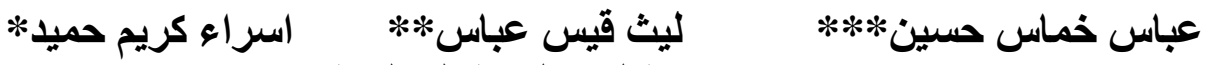

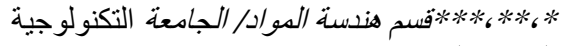 \\ abbas2000x@gmail.com البريد الالكتروني:

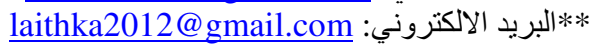 \\ sosaalmalky801@gmail.com البريد الالكتروني:****
}

\section{الخلاصة}

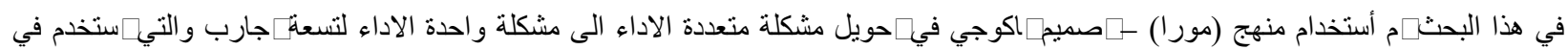

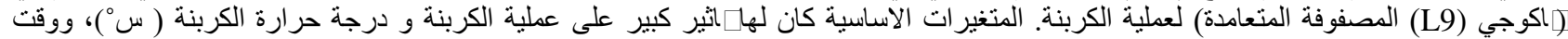

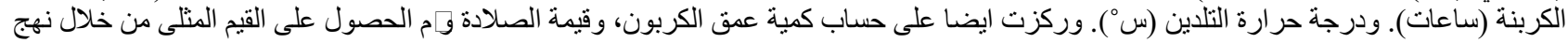

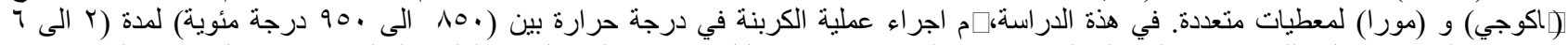

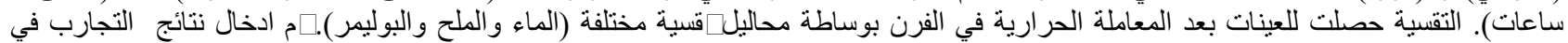

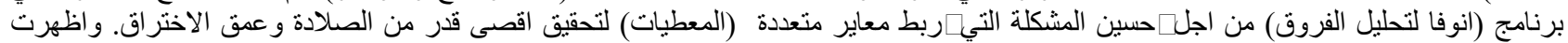

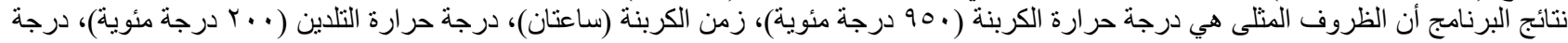

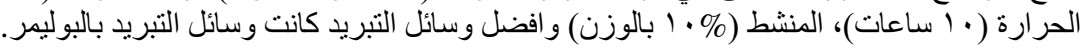

